\title{
ANNUAL BIBLIOGRAPHY*
}

\section{Art and Archaeology}

Books and Articles

Amitai, Reuven, and Michal Biran, eds. Nomads as Agents of Cultural Change: The Mongols and Their Eurasian Predecessors. Honolulu: University of Hawai'i Press, 2015.

Barnes, Gina L. Archaeology of East Asia: The Rise of Civilization in China, Korea and Japan. Oxford: Oxbow, 2015.

Bertrand, Arnaud. "La formation de la Commanderie Impériale de Dunhuang (Gansu) des Han Antérieurs: l'apport des Sources Archéologiques." Arts Asiatiques 70 (2015), 64-76.

Bemmann, Jan, and Michael Schmauder, eds. Complexity of Interaction along the Eurasian Steppe Zone in the First Millennium CE. Bonn: Vorund Frühgeschichtliche Archäologie, Rheinische FriedrichWilhelms-Universität, 2015.

Cai Dawei et al. "Molecular Archaeological Research on Ancient Cattle from the Early Bronze Age Changning Site, Qinghai Province." Asian Archaeology 3 (2015).

Cheng Jingtang et al. "Discovery and Understanding of the Neolithic Weijiawopu Site in Chifeng City, Inner Mongolia Autonomous Region," trans. Tao Li. Chinese Cultural Relics 2.1-2 (2015), 246-54.

Chen Xuan. Eastern Han ( $A D$ 25-220) Tombs in Sichuan. Oxford: Archaeopress, 2015.

Demattè, Paola. "Travel and Landscape: The Zuo River Valley Rock Art of Guangxi Zhuang Autonomous Region, China." Antiquity 89.345 (2015), 613-28.

Farrar, Lara. "Tomb from a Lost Tribe." Archaeology March/ April (2016).

Farrar, Lara. "The Price of Tea in China." Archaeology May/June (2016).

Giele, Enno. "Private Letter Manuscripts from Early Imperial China." In A History of Chinese Letters and Epistolary Culture, ed. Antje Richter, 399-474. Leiden: Brill, 2015.

Hein, Anke. "Environmental Preconditions and Human Response: Settlement Patterns and Subsistence Practices in the Prehistoric

* Compiled by Wenyi Huang, McGill University; email: wenyi.huang@mail.mcgill.ca.

(c) The Society for the Study of Early China and Cambridge University Press 2016 
Liangshan Region, Southwest China." Asian Archaeology 3 (2015), 3994 .

Kim Minku. "Claims of Buddhist Relics in the Eastern Han Tomb Murals at Horinger: Issues in the Historiography of the Introduction of Buddhism to China." Ars Orientalis 44 (2014), 134-54. Honeychurch, William. Inner Asia and the Spatial Politics of Empire: Archaeology, Mobility, and Culture Contact. New York: Springer, 2015. Hsu Yiu-Kang, Peter J. Bray, Peter Hommel, A. Mark Pollard, and Jessica Rawson. "Tracing the Flows of Copper and Copper Alloys in the Early Iron Age Societies of the Eastern Eurasian Steppe." Antiquity 90.350 (2016), 357-75.

Jacobson-Tepfer, Esther. The Hunter, the Stag, and the Mother of Animals: Image, Monument, and Landscape in Ancient North Asia. Oxford: Oxford University Press, 2015.

Lai Guolong. "Colors and Color Symbolism in Early Chinese Ritual Art: Red and Black and the Formation of the Five Colors System." In Color in Ancient and Medieval East Asia, ed. Mary M. Dusenbury. New Haven: Yale University Press, 2015.

Li Guang'an. "Bronze Artifacts of the Barony of Xu Unearthed in Gucheng County, Hubei Province," trans. Paul Nicholas Vogt. Chinese Cultural Relics 2.1-2 (2015), 270-74.

Li Meitian. "Gilt Coffin Ornaments from Han Dynasty Tombs in Wushan County: In the Context of Coffin Decoration Customs during the Han Dynasty," trans. Catrin Kost. Chinese Cultural Relics 2.1-2 (2015), 222-31.

Li Xiaocen et al. "A Study of Ancient Paper Fragments from an Eastern Han Dynasty Tomb in Minfeng County, Xinjiang Uygur Autonomous Region," trans. Annie Chan. Chinese Cultural Relics 2.1-2 (2015), 366-70.

Liu, Cary Y. "Concepts of Architectural Space in Historical Chinese Thought." In A Companion to Chinese Art, ed. Martin J. Powers and Katherine R. Tsiang, 195-211. Chichester: Wiley-Blackwell, 2015.

Lopes, R. O. "Securing the Harmony between the High and the Low. Power Animals and Symbols of Political Authority in Ancient Chinese Jades and Bronzes." Asian Perspectives: The Journal of Archaeology for Asia and the Pacific 53.2 (2014), 195-225.

Ma Juncai. "An Ivory Chariot Bracket of the Spring and Autumn Period Unearthed at the Ancient City of the Duchy of Zheng and the State of Han," trans. Garry Guan. Chinese Cultural Relics 2.1-2 (2015), 360-65. Mair, Victor H., and Liam Kelley, eds. Imperial China and Its Southern Neighbours. Singapore: Institute of East Asian Studies, 2015. 
Miller, Allison R. "Emperor Wen's 'Baling' Mountain Tomb: Innovation in Political Rhetoric and Necropolis Design in Early China." Asia Major, 3rd series, 28.2 (2015), 1-37.

Miyamoto, Kazuo. "The Initial Spread of Early Agriculture into Northeast Asia." Asian Archaeology 3 (2015), 11-26.

Nickel, Lukas. "Bricks in Ancient China and the Question of Early Cross-Asian Interaction." Arts Asiatiques 70 (2015), 49-62.

Pan Ling. "The Transformation of Cultural Exchange between North China and the Eurasian Steppe from the Late Warring States Period to the Middle Western Han." Asian Archaeology 3 (2015), 95-106.

Psarras, Sophia-Karin. Han Material Culture: An Archaeological Analysis and Vessel Typology. Cambridge, UK: Cambridge University Press, 2015.

Rawson, Jessica. "Ornament in China." In A Companion to Chinese Art, ed. Martin J. Powers and Katherine R. Tsiang, 371-91. Chichester: Wiley-Blackwell, 2015.

Rawson, Jessica. "Steppe Weapons in Ancient China and the Role of Hand-to-hand Combat." The National Palace Museum Research Quarterly 33.1 (2015), 37-95.

School of History and Culture, Shandong University. "The Excavation of the Han Dynasty Tombs of Dianyi Cemetery in Fuling District of Chongqing Municipality," trans. Zhengdong Guo. Chinese Cultural Relics 2.1-2 (2015), 88-103.

Shandong Provincial Institute of Cultural Relics and Archaeology; Qingzhou Municipal Museum. "The Excavation of a Warring States Period Tomb at Xixin Village in Qingzhou City, Shandong Province," trans. Catrin Kost. Chinese Cultural Relics $2.1-2$ (2015), 52-87.

Shi Jie. "The Overseeing Mother: Revisiting the Frontal-Pose Lady in the Wu Family Shrines in Second-Century China." Monumenta Serica 63.2 (2015), 263-93.

Shi Jie. "Rolling between Burial and Shrine: A Tale of Two Chariot Processions at Chulan Tomb 2 in Eastern Han China (171 C.E.)." Journal of the American Oriental Society 135.3 (2015), 433-52.

Weisskopf, Alison, Ling Qin, Jinglong Ding, Pin Ding, Guoping Sun, and Dorian Q. Fuller. "Phytoliths and Rice: From Wet to Dry and Back Again in the Neolithic Lower Yangtze." Antiquity 89.347 (2015), 1051-63.

Williams, James T. "Demography and Conflict during the Warring States and Han Periods in Northern Liaoning." Asian Archaeology 3 (2015), 1-10. 
Wu Hung. “The Art of 'Ritual Artifacts' (Liqi 禮器): Discourse and Practice." In A Companion to Chinese Art, ed. Martin J. Powers and Katherine R. Tsiang, 235-53. Chichester: Wiley-Blackwell, 2015.

Xiang Zhang. "Ding-Tripod of the Marquis Bao of Zeng in the Suizhou

Museum Collection," trans. Yuting Gao. Chinese Cultural Relics 2.1-2 (2015), 266-69.

Yang Xiaoneng. "Art and Early Chinese Archaeological Materials." In A Companion to Chinese Art, ed. Martin J. Powers and Katherine R. Tsiang, 91-112. Chichester: Wiley-Blackwell, 2015.

Yang Yuanzheng. "Taotie, Dragon, Phoenix, and Farmer: A Highly Decorated Qin Excavated from Jiuliandun." Early China 38 (2015), 129-50.

Yao, Alice. The Ancient Highlands of Southwest China: From the Bronze Age to the Han Empire. Oxford: Oxford University Press, 2016.

Zhao Binfu et al. "Comparative Analysis of Economic Activities during the Neolithic in the Sanjiang Plain and the Middle and Lower Heilongjiang River Valley." Asian Archaeology 3 (2015), 27-38.

Zhao Dongyue et al. "Paleopathological Study of Human Remains from the Bronze Age Shilinggang Site in Nujiang, Yunnan, Southwest China." Asian Archaeology 3 (2015), 129-44.

Zhu Naicheng. "On the Jade Human-and-Beast Double-Sided Relief Carving in the Palace Museum Collection," trans. Chao Huang. Chinese Cultural Relics 2.1-2 (2015), 211-21.

\section{Reviews}

Steinke and Ching. Art and Archaeology of the Erligang Civilization. Mei Jianjun. Bulletin of School of Oriental and African Studies 78.3 (2015), 649-51.

Shelach. The Archaeology of Early China: From Prehistory to the Han Dynasty. Barnes, Gina L. Bulletin of School of Oriental and African Studies 79.1 (2016), 214-15.

Underhill, ed. A Companion to Chinese Archaeology. Lander, Brian. Early China 38 (2015), 233-36.

\section{History}

Books and Articles

Baccini, Giulia. "The Shiji Chapter 'Guji Liezhuan' (Traditions of Witty Remonstrants): A Source to Look for Rhetorical Strategies in Early 
China." In Views from Within, Views from Beyond: Approaches to the Shiji as an Early Work of Historiography, ed. Hans van Ess et al., 103-30. Wiesbaden: Harrassowitz Verlag, 2015.

Brindley, Erica Fox. "Layers of Meaning: Hairstyle and Yue Identity in Ancient Chinese Texts." In Imperial China and Its Southern Neighbors, ed. Victor Mair and Liam Kelley, 16-42. Singapore: Institute for Southeast Asian Studies, 2015.

Bueno, André. "Roman Views of the Chinese in Antiquity." SinoPlatonic Papers 261 (2016).

Childs-Johnson, Elizabeth. "Postscript to Big Ding and China PowerShang Sifang Cosomology." In Jinian Sun Zuoyun jiaoshou bainian danchen ji gudai Zhongguo lishi yu wenhua guoji xueshu yantaohui lunwen ji 紀念孫作雲教授百年誕辰暨古代中國歷史與文化國際學術 研討會論文集 (Proceedings Commemorating the Centennial of Sun Zuoyun), 191-210. Henan University, 2012.

Childs-Johnson, Elizabeth. "Fu Zi, the Shang Woman Warrior Revisited." In A Festschrift in Honor of Professor Lily Xiao Hong Lee, ed. Shirley Chan, Barbara Hendrischke, and Sue Wiles, 5-10. Sydney: The Oriental Society of Australia, 2014.

Durrant, Stephen. "Ban Biao, Ban Gu, Their Five Shiji Sources, and the Curious Case of Chu Han chunqiu." In Views from Within, Views from Beyond: Approaches to the Shiji as an Early Work of Historiography, ed. Hans van Ess et al., 217-42. Wiesbaden: Harrassowitz Verlag, 2015.

Fuehrer, Bernhard. "Sima Qian as a Reader of Master Kong's Utterances." In Views from Within, Views from Beyond: Approaches to the Shiji as an Early Work of Historiography, ed. Hans van Ess, Olga Lomová, and Dorothee Schaab-Hanke, 9-30. Wiesbaden: Harrassowitz Verlag, 2015.

Galvany, Albert. "Signs, Clues and Traces: Anticipation in Ancient Chinese Political and Military Texts." Early China 38 (2015), 151-93.

Harbsmeier, Christoph. "Living up to Contrasting Portraiture: Plutarch on Alexander the Great and Sima Qian on the First Qin Emperor." In Views from Within, Views from Beyond: Approaches to the Shiji as an Early Work of Historiography, ed. Hans van Ess et al., 263-96. Wiesbaden: Harrassowitz Verlag, 2015.

Kern, Martin. "The 'Masters' in the Shiji." T'oung Pao 101.4-5 (2015), $335-62$.

Khayutina, Maria. "King Wen, a Settler of Disputes or Judge? The 'YuRui case' in the Historical Records and Its Historical Background." Bochumer Jahrbuch zur Ostasienforschung 38 (2015), 261-76.

Kominami, Ichirō. "The School System in Ancient China." Acta Asiatica 109 (2015). 
Kroll, Juri L. "Toward a Study of the Concept of Linear Time in the Shiji." In Views from Within, Views from Beyond: Approaches to the Shiji as an Early Work of Historiography, ed. Hans van Ess et al., 31-40. Wiesbaden: Harrassowitz Verlag, 2015.

L'Haridon, Béatrice. "The Merchants in Shiji: An Interpretation in the Light of Later Debates." In Views from Within, Views from Beyond: Approaches to the Shiji as an Early Work of Historiography, ed. Hans van Ess et al., 171-92. Wiesbaden: Harrassowitz Verlag, 2015.

Lewis, Mark Edward. "Early Imperial China, from the Qin and Han through Tang." In Fiscal Regimes and the Political Economy of Premodern States, ed. Andrew Monson and Walter Scheidel, 282307. Cambridge, UK: Cambridge University Press, 2015.

Li Wai-yee. "Historical Understanding in 'The Account of the Xiongnu' in the Shiji." In Views from Within, Views from Beyond: Approaches to the Shiji as an Early Work of Historiography, ed. Hans van Ess et al., 79-102. Wiesbaden: Harrassowitz Verlag, 2015.

Lien, Y. Edmund. "Reconstructing the Postal Relay System of the Han Period." In A History of Chinese Letters and Epistolary Culture, ed. Antje Richter, 15-52. Leiden: Brill, 2015.

Liu Kewei. "A Discussion of the Han Dynasty's Systems of Coffin Bestowal." Journal of Chinese Studies 60 (2015), 25-51.

Loewe, Michael. Problems of Han Administration: Ancestral Rites, Weights and Measures, and the Means of Protest. Leiden: Brill, 2016.

Miller, Allison R. "Jade, Imperial Identity, and Sumptuary Reform in Jia Yi's Xin shu." Dao 15.1 (2016), 103-21.

Miller, Harry, trans. The Gongyang Commentary on The Spring and Autumn Annals: A Full Translation. New York: Palgrave Macmillan, 2015.

Milburn, Olivia, trans. The Spring and Autumn Annals of Master Yan. Leiden: Brill, 2016.

Nivison, David S. "Two Studies in Shang Chronology and Warring States Historiography." Bulletin of the Jao Tsung-I Academy of Sinology 饒宗臨國學院院刊 2 (2015), 1-29.

Nienhauser, William Jr. "Takigawa Kametarō and His Contributions to the Study of the Shiji." In Views from Within, Views from Beyond: Approaches to the Shiji as an Early Work of Historiography, ed. Hans van Ess et al., 243-62. Wiesbaden: Harrassowitz Verlag, 2015.

Nienhauser, William Jr., ed. The Grand Scribe's Records_Volume X: The Memoirs of Han China, Part III. Bloomington: Indiana University Press, 2016.

Nylan, Michael. "Assets Accumulating: Sima Qian's Perspective on Moneymaking, Virtue, and History." In Views from Within, Views from Beyond: Approaches to the Shiji as an Early Work of 
Historiography, ed. Hans van Ess et al., 131-70. Wiesbaden: Harrassowitz Verlag, 2015.

Razeto, Anna. "Comparing East and West: Aspects of Urban Manufacture and Retail in the Capitals of the Roman and Han Empires." In Making Ancient Cities: Space and Place in Early Urban Societies, ed. Andrew T. Creekmore III and Kevin D. Fisher, 337-69. Cambridge, UK: Cambridge University Press, 2014.

Richter, Antje. "Between Letter and Testament: Letters of Familial Admonition in Han and Six Dynasties China." In A History of Chinese Letters and Epistolary Culture, ed. Antje Richter, 239-75. Leiden: Brill, 2015.

Scheidel, Walter, ed. State Power in Ancient China and Rome. Oxford: Oxford University Press, 2015.

Selbitschka, Armin. "Early Chinese Diplomacy: Realpolitik versus the So-Called Tributary System." Asia Major, 3rd series, 28.1 (2015), 61-114.

Shin Hyeon. "Aspects of Study of the Confucian Classics during the Han: The Formation of Cosmological 'Knowledge.'" Acta Asiatica 105 (2015).

Vankeerberghen, Griet. "History, Historical Communication, and the 32 BCE Restoration of the Kingdom of Hejian." In An Integrated Vision of Chinese Scholarship: Literature, History, and Philosophy, 59-70, ed. Ching-I Tu, Xin Ning, and Dietrich Tschanz. New Brunswick: Confucius Institute of Rutgers University, 2015.

Van Ess, Hans. "The Friends of Sima Tan and Sima Qian." In Views from Within; Views from Beyond. Approaches to the Shiji as an Early Work of Historiography, ed. Hans van Ess, Olga Lomová, and Dorothee Schaab-Hanke, 67-77. Wiesbaden: Harrassowitz Verlag, 2015.

Wang Haicheng. Writing and the Ancient State: Early China in Comparative Perspective. Cambridge, UK: Cambridge University Press, 2014.

Weingarten, Oliver. "What Did Disciples Do? Dizi 弟子 in Early Chinese Texts." Harvard Journal of Asiatic Studies 75.1 (2015), 29-75.

Wong, John D. "The Shifting Concept of Space and Territory during the Warring States Era." Asia Major, 3rd series, 28.1 (2015), 1-35.

Yang Jidong. "Transportation, Boarding, Lodging, and Trade along the Early Silk Road: A Preliminary Study of the Xuanquan Manuscripts." Journal of the American Oriental Society 135.3 (2015), 421-32.

Yates, R. D. S. "Searching for Peace in the Warring States." In Peace in the Ancient World: Concepts and Theories, ed. K. A. Raaflaub, 98-121. Malden, MA: Wiley Blackwell, 2016.

Zhang Qizhi. An Introduction to Chinese History and Culture. Berlin: Springer, 2015. 
Zhao Lu. "To Become Confucius: The Apocryphal Texts and Eastern Han Emperor Ming's Political Legitimacy." Asia Major, 3rd series, 28.1 (2015), 115-44.

\section{Reviews}

Brashier. Public Memory in Early China. Brown, Miranda. Journal of Chinese Studies 61 (2015), 301-4.

Brashier. Public Memory in Early China. Durrant, Stephen. American Historical Reviews 120.5 (2015), 1869-70.

Brashier. Public Memory in Early China. Villagran, Ignacio. Journal of Asian Studies 75.1 (2016), 212-13.

Brashier. Public Memory in Early China. Van Ess, Hans. Monumenta Serica 63.2 (2015), 441-46.

Cai. Witchcraft and the Rise of the First Confucian Empire. Nylan, Michael. Journal of Chinese Studies 43.2 (2015), 196-99.

Cai. Witchcraft and the Rise of the First Confucian Empire. Van Ess, Hans. Journal of Chinese Studies 6o (2015), 341-46.

Cai. Witchcraft and the Rise of the First Confucian Empire. Brindley, Erica Fox. American Historical Reviews 120.3 (2015), 988-89.

Cai. Witchcraft and the Rise of the First Confucian Empire. Sou, Daniel. Religious Studies Review 41.4 (2015), 210-11.

Cai. Witchcraft and the Rise of the First Confucian Empire. Sanft, Charles. Chinese Historical Review 22.2 (2015), 180-82.

Chin. Savage Exchange: Han Imperialism, Chinese Literary Style, and the Economic Imagination. Von Falkenhausen, Lothar. Journal of Chinese Studies 61 (2015), 325-39.

Chin. Savage Exchange: Han Imperialism, Chinese Literary Style, and the Economic Imagination. Zufferey, Nicolas. Bulletin of School of Oriental and African Studies 78.3 (2015), 646-48.

Chin. Savage Exchange: Han Imperialism, Chinese Literary Style, and the Economic Imagination. Habberstad, Luke. Journal of the American Oriental Society 135.2 (2015), 414-17.

Kinney, trans. and ed. Exemplary Women of Early China: The Lienü zhuan of Liu Xiang. Wang, Robin R. Journal of the American Oriental Society 135.2 (2015), 417-18.

Kinney, trans. and ed. Exemplary Women of Early China: The Lienü zhuan of Liu Xiang. Nylan, Michael, and Benjamin Daniels. Philosophy East and West 66.2 (2016), 662-66.

Kinney, trans. and ed. Exemplary Women of Early China: The Lienü zhuan of Liu Xiang. Hinsch, Bret. Nan Nü: Men, Women and Gender in Early and Imperial China 17.2, 309-12. 
Kline and Tiwald. Ritual and Religion in the Xunzi. Hagen, Kurtis. Philosophy East and West 66.2 (2016), 676-78.

Lorge. Chinese Martial Arts from Antiquity to the Twenty-first Century. Yates, Robin D. S. Journal of Chinese Military History 4 (2015), 214-17.

Pines, Shelach, von Falkenhausen, and Yates, eds. Birth of an Empire: The State of Qin Revisited. Brown, Miranda. Journal of Chinese Studies 60 (2015), 332-35.

Raphals. Divination and Prediction in Early China and Ancient Greece. Shaughnessy, Edward L. Journal of Chinese Studies 60 (2015), 319-31.

Raphals. Divination and Prediction in Early China and Ancient Greece. Sivin, Nathan. Journal of Asian Studies 75.1 (2016), 225.

Sanft. Communication and Cooperation in Early Imperial China: Publicizing the Qin Dynasty. Goldin, Paul R. Journal of Chinese Studies 6o (2015), 306-8.

Tseng. Picturing Heaven in Early China. Chen Jianing. Early China 38 (2015), 243-44.

Wang. Writing and the Ancient State: Early China in Comparative Perspective. Yao, Alice. Cambridge Archaeological Journal 26.2 (2016), 369-70.

Wang. Writing and the Ancient State: Early China in Comparative Perspective. Campbell, Roderick. Journal of Asian Studies 74.4 (2015), 1009-10.

Wang. Writing and the Ancient State: Early China in Comparative Perspective. Krijgsman, Rens. Early China 38 (2015), 237-40.

\section{Literature}

Books and Articles

Durrant, Stephen W., et al. The Letter to Ren An and Sima Qian's Legacy. Seattle: University of Washington Press, 2016.

Liu Jianmei. Zhuangzi and Modern Chinese Literature. Oxford: Oxford University Press, 2016.

Smith, Jonathan. "Sound Symbolism in the Reduplicative Vocabulary of the Shijing." Journal of Chinese Literature and Culture 2.2 (2015), 258-85.

Song Chenqing. "Tonal Contrast in Early Pentasyllabic Poems: A Quantitative Study of Three Poem Collections." Journal of Chinese Literature and Culture 2.2 (2015), 324-46.

Weingarten, Oliver. "The Figure of Yan Zhuoju 顏瓬聚 in Ancient Chinese Literature." Monumenta Serica 63.2 (2015), 229-61. 
Zhao Minli and Benjamin Ridgway. "A Discussion of the Principles for the Combination of 'Feet' in the Pentasyllabic shi Genre." Journal of Chinese Literature and Culture 2.2 (2015), 286-323.

\title{
Paleography and Excavated Texts
}

\author{
Books and Articles
}

Allan, Sarah. Buried Ideas: Legends of Abdication and Ideal Government in Early Chinese Bamboo-Slip Manuscripts. New York: SUNY Press, 2015. Anicotte, Rémi. "Bidimensional Expressions of Fractions in Chinese." Cahiers de Linguistique Asie Orientale 44.1 (2015), 36-56.

Brindley, Erica Fox. "Spontaneous Arising: Creative Change in the Hengxian." Journal of Daoist Studies 9 (2016), 1-17.

Chen Wei. "A Few Issues Regarding the Statutes on Corvée Labor in the Yuelu Academy Qin Dynasty Bamboo Slip Manuscripts," trans. Christopher J. Foster. Chinese Cultural Relics 2.1-2 (2015), 275-82.

Lau, Ulrich, and Thies Staack. Legal Practice in the Formative Stages of the Chinese Empire: An Annotated Translation of the Exemplary Qin Criminal Cases from the Yuelu Academy Collection. Leiden: Brill, 2016.

Li Junming. "An Overview of the Emperor Gaozong of the Yin (Shang) Dynasty Asking San Shou from the Tsinghua Bamboo Slips," trans. Paul Nicholas Vogt. Chinese Cultural Relics 2.1-2 (2015), 255-65.

McDaniel, Justin Thomas, and Lynn Ransom, eds. From Mulberry Leaves to Silk Scrolls: New Approaches to the Study of Asian Manuscript Traditions. Philadelphia: University of Pennsylvania Press, 2015.

Park Haeree. The Writing System of Scribe Zhou: Evidence from Late Pre-imperial Chinese Manuscripts and Inscriptions (5th-3rd Centuries BCE). Berlin: De Gruyter, 2016.

Perkins, Franklin. "Five Conducts (Wu Xing 五行) and the Grounding of Virtue." Journal of Chinese Philosophy 41.3-4 (2015), 503-20.

Perkins, Franklin. "Fanwu liuxing 凡物流形 ("All Things Flow into Form') and the 'One' in the Laozi." Early China 38 (2015), 195-232.

Schwermann, Christian, and Wang Ping. "Female Human Sacrifice in Shang-Dynasty Oracle-Bone Inscriptions." International Journal of Chinese Character Studies 1.1 (2015), 49-83.

Takashima, Ken-ichi. A Little Primer of Chinese Oracle-Bone Inscriptions with Some Exercises. Wiesbaden: Harrassowitz Verlag, 2015.

\section{Reviews}

Cook. The Bamboo Texts of Guodian: A Study and Complete Translation. Williams, Crispin. Journal of Asian Studies 75.1 (2016), 216-18. 
Lau and Lüdke. Exemplarische Rechtsfälle vom Beginn der Han-Dynastie: Eine kommentierte Übersetzung des Zouyanshu aus Zhangjiashan/ Provinz Hubei. MacCormack, Geoffrey. Asiatische Studien: Études Asiatiques 69.2 (2015), 511-18.

Shaughnessy. Unearthing the Changes: Recently Discovered Manuscripts of the Yi Jing (I Ching) and Related Texts. Kalinowski, Marc. T'oung Pao 101.1-3 (2015), 239-45.

\section{Philology and Linguistics}

Books and Articles

Bottéro, Françoise. "The Concept of shěng 省 in Shuōwén jiězì." International Journal of Chinese Character Studies 1.1 (2015), 15-47.

Chappell, Hilary M. Diversity in Sinitic Languages. Oxford: Oxford University Press, 2016.

Huot, Claire. "The Dog-Eared Dictionary: Human-Animal Alliance in Chinese Civilization." Journal of Asian Studies 74.3 (2015), 589-613.

Meisterernst, Barbara. Tense and Aspect in Han Period Chinese: A Linguistic Analysis of the "Shìji." Berlin: De Gruyter, 2015.

Meisterernst, Barbara. New Aspects of Classical Chinese Grammar. Wiesbaden: Harrassowitz Verlag, 2016.

Ming, Thomas. "Who Does the Sounding? The Metaphysics of the FirstPerson Pronoun in the Zhuangzi." Dao 15.1 (2016), 57-79.

Sun Zhenbin. Language, Discourse, and Praxis in Ancient China. Berlin: Springer, 2015.

\section{Reviews}

Kroll. A Student's Dictionary of Classical and Medieval Chinese. Barrett, T. H. Bulletin of School of Oriental and African Studies 78.3 (2015), 648-49.

\section{Religion and Philosophy}

Books and Articles

Allen, Barry. Vanishing into Things: Knowledge in Chinese Tradition. Cambridge, MA: Harvard University Press, 2015.

Allinson, Robert Elliott. "Of Fish, Butterflies and Birds: Relativism and Nonrelative Valuation in the Zhuangzi." Asian Philosophy 25.3 (2015), 238-52. 
Allinson, Robert Elliott. "How to Say What Cannot Be Said: Metaphor in the Zhuangzi." Journal of Chinese Philosophy 41.3-4 (2015), 268-86.

Arghiresco, Diana. De la Continuité Dynamique dans l'univers Confucéen: Lecture Néoconfucéenne du Zhongyong (中庸): Nouvelle Traduction du Chinois Classique et Commentaire Herméneutique (Of Dynamic Continuity in the Confucian Universe: A Neo-Confucian Reading of the Zhongyong: A New Translation from the Classical Chinese and a Hermeneutical Commentary). Paris: Les Éditions du Cerf, 2013.

Bell, Daniel A. "Reconciling Confucianism and Nationalism." Journal of Chinese Philosophy 41.1-2 (2015), 33-54.

Bender, Jacob. "Justice as the Practice of Non-Coercive Action: A Study of John Dewey and Classical Daoism." Asian Philosophy 26.1 (2016), 20-37.

Berger, Douglas L. Encounters of Mind: Luminosity and Personhood in Indian and Chinese Thought. New York: SUNY Press, 2015.

Berthel, Ken. "How Did Zhong Ziqi Understand Bo Ya's Heart-Mind?" Philosophy East and West 66.1 (2016), 259-70.

Blahuta, Jason P. Fortune and the Dao: A Comparative Study of Machiavelli, the Daodejing, and the Han Feizi. Lanham, MD: Lexington, 2015.

Brons, Lajos L. "Wang Chong, Truth, and Quasi-Pluralism." Chinese Philosophy 6.1 (2015), 129-48.

Chen Guying. "The Tradition of Emotive Writing in the Zhuangzi and Its Echoes in Later Generations." Frontiers of Philosophy in China 10.3 (2015), 340-52.

Chen Na. "Why Is Confucianism Not a Religion? The Impact of Orientalism." Zygon: Journal of Religion and Science 51.1 (2016), 21-42.

Chen Xunwu. "The Value of Authenticity: Another Dimension of Confucian Ethics." Asian Philosophy 25.2 (2015), 172-87.

Chen Xunwu. "The Problem of Mind in Confucianism." Asian Philosophy 26.2 (2016), 166-81.

Chiu Wai Wai. "Zhuangzi's Idea of 'Spirit': Acting and 'Thinging Things' without Self-Assertion." Asian Philosophy 26.1 (2016), 38-51.

Cline, Erin M. Families of Virtue: Confucian and Western Views on Childhood Development. New York: Columbia University Press, 2015.

Cook, Scott. "Confucius as Seen through the Lenses of the Zuo zhuan and Lunyu." T'oung Pao 101.4-5 (2015), 298-334.

D'Ambrosio, Paul. "Authenticity in the Zhuangzi? Contemporary Misreadings of zhen 真 and an Alternative to Existentialism." Frontiers of Philosophy in China 10.3 (2015), 353-79.

Defoort, Carine. "The Modern Formation of Early Mohism: Sun Yirang's Exposing and Correcting the Mozi." T'oung Pao 101.1-3 (2015), 208-38.

Defoort, Carine. "Heavy and Light Body Parts: The Weighing Metaphor in Early Chinese Dialogues." Early China 38 (2015), 55-77. 
Duperon, Matthew L. "The Role of Qing 情 in the Huainanzi's Ethics." Early China 38 (2015), 79-107.

Eskildsen, Stephen. Daoism, Meditation, and the Wonders of Serenity: From the Latter Han Dynasty (25-220) to the Tang Dynasty (618-907). New York: SUNY Press, 2015.

El Amine, Loubna. Classical Confucian Political Thought: A New Interpretation. Princeton: Princeton University Press, 2015.

Farrugia, Mark L. "To Die or Not to Die: Zhuangzi's Three Immortalities." Frontiers of Philosophy in China 10.3 (2015), 380-414.

Field, Stephen L., trans. The Duke of Zhou Changes: A Study and Annotated Translation of the Zhouyi 周易. Wiesbaden: Harrassowitz Verlag, 2015.

Fischer, Paul. "The Creation of Daoism." Journal of Daoist Studies 8 (2015), 1-23.

Foust, Mathew A. "Confucianism and American Pragmatism." Philosophy Compass 10.6 (2015), 369-78.

Frühauf, Manfred. "Mythologie und Astronomie im Mu tianzi zhuan 穆天子傳." Bochumer Jahrbuch zur Ostasienforschung 38 (2015), 245-60.

$\mathrm{Fu}$ Youde and Wang Qiangwei. "A Comparison of Filial Piety in Ancient Judaism and Early Confucianism," trans. Noah Lipkowitz. Journal of Chinese Humanities 1.2 (2015), 280-312.

Fung Yiu-ming. "Ren 仁 as a Heavy Concept in the Analects." Journal of Chinese Philosophy 41.1-2 (2015), 91-113.

Guarde-Paz, César. "Moral Dilemmas in Chinese Philosophy: A Case Study of the Lienü zhuan." Dao 15.1 (2016), 81-101.

Guzowska, Joanna. "The Spatiality of Cognition in the Zhuangzi." Frontiers of Philosophy in China 10.3 (2015), 415-29.

Harbsmeier, Christoph. "On the Nature of Early Confucian Classical Chinese Discourse on Ethical Norms." Journal of Value Inquiry 49.4 (2015), 517-41.

Hendrischke, Barbara. "Views on Prognostication in Early Religious Daoism." Bochumer Jahrbuch zur Ostasienforschung 38 (2015), 345-56.

Hoffert, Brian. "Beyond Life and Death: Zhuangzi's Great Awakening." Journal of Daoist Studies 8 (2015), 165-78.

Huang Kejian. From Destiny to Dao: A Survey of Pre-Qin Philosophy in China. Honolulu, HI: Enrich Professional Publishing, 2015.

Huff, Benjamin I. "Eudaimonism in the Mencius: Fulfilling the Heart." Dao 14.3 (2015), 403-31.

Hutton, Eric L. "On the 'Virtue Turn' and the Problem of Categorizing Chinese Thought." Dao 14.3 (2015), 331-53.

Ing, Michael. “Born of Resentment: Yuan 怨 in Early Confucian Thought." Dao 15.1 (2016), 19-33.

Jeffrey, David Lyle. "The 'Good' and 'The Good Life': Confucius and Christ." Journal of Chinese Humanities 1.2 (2015), 213-30. 
Jiang Tao. "The Problem of Authorship and the Project of Chinese Philosophy: Zhuang Zhou and the Zhuangzi between Sinology and Philosophy in the Western Academy." Dao 15.1 (2016), 35-55.

Jiang Xinyan. "Mengzi and the Archimedean Point for Moral Life." Journal of Chinese Philosophy 41.1-2 (2015), 74-90.

Jiang Xinyan. Yingyu shijie zhong de Zhongguo zhexue 英語世界中的中國 哲學 (Chinese Philosophy in the English-Speaking World). Journal of Chinese Philosophy 41.3-4 (2015), 527-30.

Kim Sungmoon. "Achieving the Way: Confucian Virtue Politics and the Problem of Dirty Hands." Philosophy East and West 66.1 (2016), 152-76.

King, R. A. H., ed. The Good Life and Conceptions of Life in Early China and Graco-Roman Antiquity. Berlin: De Gruyter, 2015.

Li Chenyang and Franklin Perkins, eds. Chinese Metaphysics and Its Problems. Cambridge, UK: Cambridge University Press, 2015.

Li, Xiaofan Amy. "The Notion of Originality and Degrees of Faithfulness in Translating Classical Chinese: Comparing Translations of the Liezi." Early China 38 (2015), 109-28.

Lim Tae-seung. "Signs of the Sacred: The Confucian Body and Symbolic Power." Philosophy East and West 65.4 (2015), 1030-51.

Liu Guozhong. Introduction to the Tsinghua Bamboo-Strip Manuscripts, trans. Christopher Foster and William N. French. Leiden: Brill, 2016.

Liu Qingping. "On the Possibility of Universal Love for All Humans: A Comparative Study of Confucian and Christian Ethics." Asian Philosophy 25.3 (2015), 225-37.

Liu Xiaogan, ed. Dao Companion to Daoist Philosophy. Berlin: Springer, 2015.

Lo Ping-cheung and Sumner B. Twiss, eds. Chinese Just War Ethics Origin, Development, and Dissent. London: Routledge, 2015.

Ma Lin. "A Zhuangzian Response to Heidegger's Mitsein." Journal of Chinese Philosophy 41.3-4 (2015), 487-502.

Ma Lin. "Thinking with Zhuangzi and Su Shi against Heidegger on Artwork." Philosophy East and West 65.3 (2015), 809-45.

Machek, David. "'Emotions That Do Not Move': Zhuangzi and Stoics on Self-Emerging Feelings." Dao 14.4 (2015), 521-44.

Machek, David. "Beyond Sincerity and Pretense: Role-Playing and Unstructured Self in the Zhuangzi." Asian Philosophy 26.1 (2016), 52-65.

Martinich, A. P., and Siwing Tsoi. "Mozi's Ideal Political Philosophy." Asian Philosophy 25.3 (2015), 253-74.

McLeod, Alexus. "Philosophy in Eastern Han Dynasty China (25-220 CE)." Philosophy Compass 10.6 (2015), 355-68.

McLeod, Alexus. Theories of Truth in Chinese Philosophy: A Comparative Approach. London: Rowman \& Littlefield, 2016. 
Meyer, Andrew. "Exploring the Construction of a Category in Warring States Sources." T'oung Pao 101.4-5 (2015), 271-97.

Michael, Thomas. "Shamanism Theory and Early Chinese Wu." Journal of the American Academy of Religion 83.3 (2015), 649-96.

Michael, Thomas. In the Shadows of the Dao: Laozi, the Sage, and the Daodejing. New York: SUNY Press, 2015.

Ming, Thomas, and Aaron Lai. "Fixing the White Horse Discourse: Zhuangzi's Proof of 'A White Horse Is Not a Horse.'” Philosophy East and West 66.1 (2016), 271-89.

Møllgaard, Eske J. "Political Confucianism and the Politics of Confucian Studies." Dao 14.3 (2015), 391-402.

Møllgaard, Eske J. "Zhuangzi's Word, Heidegger's Word, and the Confucian Word." Journal of Chinese Philosophy 41.3-4 (2015), 454-69.

Mou Bo. "Rooted and Rootless Pluralist Approaches to Truth: Two Distinct Interpretations of Wang Chong' [sic] Account." Comparative Philosophy 6.1 (2015), 149-68.

Mower, Gordon B. "Mengzi and Hume on Extending Virtue." Philosophy East and West 66.2 (2016), 475-87.

Murphy, Tim, and Ralph Weber. "Ideas of Justice and Reconstructions of Confucian Justice." Asian Philosophy 26.2 (2016), 99-118.

Nelson, Eric S. "Technology and the Way: Buber, Heidegger, and LaoZhuang 'Daoism.'" Journal of Chinese Philosophy 41.3-4 (2015), 307-27.

Nichols, Ryan. "Early Confucianism Is a System for Social-Functional Influence and Probably Does Not Represent a Normative Ethical Theory." Dao 14.4 (2015), 499-520.

Ni Peimin. Confucius: The Man and the Way of Gongfu. Lanham: Rowman \& Littlefield, 2016.

Nie Jing-bao. "Confucian Universalism for Human Rights and Global Bioethics." Bochumer Jahrbuch zur Ostasienforschung 38 (2015), 115-28.

Nylan, Michael. "Lots of Pleasure but Little Happiness." Philosophy East and West 65.1 (2015), 196-226.

Olberding, Amy. "From Corpses to Courtesy: Xunzi's Defense of Etiquette." Journal of Value Inquiry 49.1-2 (2015), 145-59.

Olberding, Amy. "It's Not Them, It's You: A Case Study Concerning the Exclusion of Non-Western Philosophy." Comparative Philosophy 6.2 (2015), 14-34.

Pankenier, David W. "Weaving Metaphors and Cosmo-Political Thought in Early China." T'oung Pao 101.1-3 (2015), 1-34.

Perkins, Franklin. "The Mozi and the Daodejing." Journal of Chinese Philosophy 41.1-2 (2015), 18-32.

Pang-White, Ann A., ed. The Bloomsbury Research Handbook of Chinese Philosophy and Gender. New York: Bloomsbury Publishing, 2016. 
Pines, Yuri, et al., eds. Ideology of Power and Power of Ideology in Early China. Leiden: Brill, 2015.

Puett, Michael, and Christine Gross-Loh. The Path: What Chinese Philosophers Can Teach Us about the Good Life. New York: Simon \& Schuster, 2016.

Queen, Sarah A., and John S. Major, trans. Luxuriant Gems of the Spring and Autumn, Attributed to Dong Zhongshu. New York: Columbia University Press, 2016.

Ramsey, John M. "Mengzi's Externalist Solution to the Role Dilemma." Asian Philosophy 25.2 (2015), 188-206.

Rosemont, Henry Jr. Against Individualism: A Confucian Rethinking of the Foundations of Morality, Politics, Family, and Religion. Lanham: Lexington Books, 2015.

Riegel, Jeffrey K. "A Root Split in Two: Mengzi 3 A $_{5}$ Reconsidered." Asia Major, 3rd series, 28.1 (2015), 37-59.

Schwartz, Adam Craig. "China's First Prayer." Journal of the American Oriental Society 135.1 (2015), 93-113.

Shen Yang. "Rethinking 'Traditions': Reading the Classics as Ritual." Journal of Chinese Humanities 1.2 (2015), 363-83.

Shun Kwong-loi. "Nivison and the Philosophical Study of Confucian Thought: In Memory of David S. Nivison (1923-2014)." Early China 38 (2015), 41-53.

Sigurđsson, Geir. Confucian Propriety and Ritual Learning: A Philosophical Interpretation. New York: SUNY Press, 2015.

Singh, Danesh. "Health as Human Nature and Critique of Culture in

Nietzsche and Zhuang Zi." Comparative Philosophy 6.1 (2015), 91-110.

Sosa, Ernest. "Confucius on Knowledge." Dao 14.3 (2015), 325-30.

Sturgeon, Donald. "Zhuangzi, Perspectives, and Greater Knowledge." Philosophy East and West 65.3 (2015), 892-917.

Tan Sor-hoon. "Xunzi and Naturalistic Ethics." Journal of Value Inquiry 49.1-2 (2015), 257-65.

Van Ess, Hans. "Reflections on the Sequence of the First Three Books of the Mengzi." Journal of Chinese Philosophy 41.3-4 (2015), 287-306.

Van Norden, Bryan W. "Zhuangzi's Ironic Detachment and Political Commitment." Dao 15.1 (2016), 1-17.

Van Brakel, Jaap. "Heidegger on Zhuangzi and Uselessness: Illustrating Preconditions of Comparative Philosophy." Journal of Chinese Philosophy 41.3-4 (2015), 387-406.

Vankeerberghen, Griet. "The Four Lost Classics: An Essay in Readership." In Dao Companion to Daoist Philosophy, ed. Liu Xiaogan, 307-23. Berlin: Springer, 2015.

Villaver, Ranie. "Does guiji Mean Egoism? Yang Zhu's Conception of Self." Asian Philosophy 25.2 (2015), 216-23. 
Wang Zhongjiang. Order in Early Chinese Texts: Natural, Supernatural, and Legal Approaches, trans. Misha Tadd. New York: Palgrave Macmillan, 2016.

Weber, Ralph. "Confucian Political Philosophy for Non-Confucians." Frontiers of Philosophy in China 10.4 (2015), 547-67.

Weingarten, Oliver. "Debates around Jixia: Argument and Intertextuality in Warring States Writings Associated with Qi." Journal of the American Oriental Society 135.2 (2015), 283-307.

Winslett, Justin. "Speaking of Gods: The Discourse of the Extrahuman in Early Chinese Texts." Journal of the British Association for Chinese Studies 5 (2016), 38-77.

$\mathrm{Xu}$ Di and Hunter McEwan. Chinese Philosophy on Teaching and Learning: Xueji in the Twenty-First Century. New York: SUNY Press, 2016.

Xiang Shuchen. "The Ghostly Other: Understanding Racism from Confucianism and Enlightenment Models of Subjectivity." Asian Philosophy 25.4 (2015), 384-401.

Yao Xinzhong. "Confucian Tradition, Modernization, and Globalization." Journal of Chinese Humanities 1.2 (2015), 241-58.

Yu Kam Por. "The Chinese Tradition of Filial Piety and the Confucian Philosophical Reconstructions." Bochumer Jahrbuch zur Ostasienforschung 38 (2015), 145-6o.

Zhao Dingxin. The Confucian-Legalist State: A New Theory of Chinese History. Oxford: Oxford University Press, 2015.

Reviews

Arghiresco. De la Continuité Dynamique dans l'univers Confucéen: Lecture Néoconfucéenne du Zhongyong (中庸): Nouvelle Traduction du Chinois Classique et Commentaire Herméneutique (Of Dynamic Continuity in the Confucian Universe: A Neo-Confucian Reading of the Zhongyong: A New Translation from the Classical Chinese and a Hermeneutical Commentary). Soffel, Christian. Philosophy East and West 65.2 (2015), 615-17.

Bai. Jiubang xinming: gujin zhongxi canzhao xia de gudian rujia zhengzhi zhexue 舊邦新命: 古今中西參照下的古典儒家政治哲學 (New Mission of an Old State: Classical Confucian Political Philosophy in a Contemporary and Comparative Relevance Perspective). Hon Tze-Ki. Journal of Chinese Philosophy 41.3-4 (2015), 523-26.

Chen. Confucianism as Religion: Controversies and Consequences. Van Ess, Hans. Journal of Chinese Religions 43.1 (2015), 94-96.

Cline. Confucius, Rawls and the Sense of Justice. Harris, Eirik Lang. Dao $14 \cdot 3$ (2015), 455-58. 
Coutinho. An Introduction to Daoist Philosophies. Kwok, Sai Hang, and Eric Nelson. Journal of Asian Studies 74.4 (2015), 1013-14.

Coutinho. An Introduction to Daoist Philosophies. Morrow, Sydney. Philosophy East and West 65.2 (2015), 623-25.

Hendrischke. The Scripture on Great Peace: The Taiping Jing and the Beginnings of Daoism. Lu, Zhao. Religious Studies Review 42.1 (2016), 59. Hutton. Xunzi: The Complete Text. Tavor, Ori. Dao 14.4 (2015), 611-14. Ing. The Dysfunction of Ritual in Early Confucianism. Tavor, Ori. History of Religions 55.1 (2015), 109-11.

Kline and Tiwald, eds. Ritual and Religion in the Xunzi. Goldin, Paul R. Journal of Chinese Religions 43.1 (2015), 102-4.

Kline III and Tiwald, eds. Ritual and Religion in the Xunzi. Stalnaker, Aaron. Dao 14.4 (2015), 615-19.

Komjathy. The Daoist Tradition: An Introduction. Olles, Volker. Journal of Chinese Religions 43.1 (2015), 104-6.

Li. The Confucian Philosophy of Harmony. Rošker, Jana S. Monumenta Serica 63.1 (2015), 201-4.

Li. The Confucian Philosophy of Harmony. Tan Sor-hoon. Philosophy East and West 65.2 (2015), 620-22.

Li. The Confucian Philosophy of Harmony. Pokorny, Lukas. Religious Studies Review 41.3 (2015), 127.

Li. Nature and Freedom: The Philosophy of Zhuangzi 自然與自由: 莊子哲學 研究. Wang Cheng. Dao 14.3 (2015), 463-66.

Liu, ed. Dao Companion to Daoist Philosophy. Yuan Ai. Frontiers of Philosophy in China 10.4 (2015), 695-97.

Malhotra. Wisdom of the Tao Te Ching: The Code of the Spiritual Warrior. Morrow, Sydney. Philosophy East and West 65.4 (2015), 1312.

Pearson. The Original I Ching: An Authentic Translation of the Book of Changes. Redmond, Geoffrey. Early China 38 (2015), 241-42.

Perkins. Heaven and Earth Are Not Humane: The Problem of Evil in Classical Chinese Philosophy. Lai, Karyn. Dao 15.1 (2016), 135-39.

Peterman. Whose Tradition? Which Dao? - Confucius and Wittgenstein on Moral Learning and Reflection. Li Puqun. Dao 14.3 (2015), 467-71.

Queen and Puett, eds. The Huainanzi and Textual Production in Early China. Zürn, Tobias Benedikt. Daoism: Religion, History and Society 7 (2015), 202-11.

Seok. Embodied Moral Psychology and Confucian Philosophy. Bockover, Mary I. Philosophy East and West 66.1 (2016), 346-48.

Smith. The I Ching: A Biography. Hudson, Nicholas. Philosophy East and West 65.2 (2015), 657-58.

Solomon. On the School of Names in Ancient China. Suter, Rafael. Asiatische Studien: Études Asiatiques 69.2 (2015), 527-37. 
Wang. Zhuangzi: Thinking through the Inner Chapters. Billeter, Jean François. Asiatische Studien: Études Asiatiques 71.1 (2016), 265.

Wang. Yinyang: The Way of Heaven and Earth in Chinese Thought and Culture. Sullivan, Ian M. Philosophy East and West 65.2 (2015), 656-57. Wang. Yinyang: The Way of Heaven and Earth in Chinese Thought and Culture. D'Ambrosio, Paul. Philosophy East and West 66.1 (2016), 351-53.

Van Norden. Introduction to Classical Chinese Philosophy. Lau Po-Hei. Journal of Chinese Philosophy 41.3-4 (2015), 521-23.

Zhan. Contested Notions on the Subjectivity in the Zhuangzi 爭論中的莊子 主體論. Yuan Ai. Dao 14.4 (2015), 621-23.

\section{Science and Technology}

Books and Articles

Golas, Peter J. Picturing Technology in China: From Earliest Times to the Nineteenth Century. Hong Kong: Hong Kong University Press, 2015.

Guan Yuzhen. "Eclipse Theory in the Jing chu li, Part I: The Adoption of Lunar Velocity." Archive for History of Exact Sciences 69.1 (2015), 103-23.

Olberding, Garret. "Movement and Strategic Mapping in Early Imperial China." Monumenta Serica: Journal of Oriental Studies 64.1 (2016), 23-46. Yang Shao-yun. "Their Lands Are Peripheral and Their Qi Is Blocked Up': The Uses of Environmental Determinism in Han (206 BCE-220 $\mathrm{CE})$ and Tang (618-907 CE) Chinese Interpretations of the 'Barbarians.'” In The Routledge Handbook of Identity and the Environment in the Classical and Medieval Worlds, ed. Rebecca Futo Kennedy and Molly Jones-Lewis, 390-412. London: Routledge, 2016. Yao Ping. "Changing Views on Sexuality in Early and Medieval China." Journal of Daoist Studies 8 (2015), 53-69.

Reviews

Jun Wenren. Ancient Chinese Encyclopedia of Technology: Translation and Annotation of Kaogong ji (The Artificers' Record). Von Falkenhausen, Lothar. East Asian Science, Technology, and Medicine 40 (2014), 100-103. 